\title{
Zuelow, E. G. E. (ed.) (2011) Touring Beyond the Nation: a Transnational Approach to European Tourism History. Ashgate. 250 pp. ISBN 978-0754666561
}

\author{
Reviewed by Craig Webster ${ }^{1}$
}

Received: 09/06/2011

\begin{abstract}
${ }^{1}$ Department of European Studies and International Relations, University of Nicosia, 46 Makedonitissas Avenue, 1700 Nicosia, Cyprus; tel. +357 22841500; e-mail: webster.c@unic.ac.cy
\end{abstract}

(c) 2011 International University College. All rights reserved

Citation: Zuelow, E. G. E. (ed.) (2011) Touring Beyond the Nation: a Transnational Approach to European Tourism History. Ashgate. 250 pp. ISBN 978-0754666561, Reviewed by Craig Webster, European Journal of Tourism Research 4(2), pp. 248-250

"Tourism Beyond the Nation" has the strengths and weaknesses of a typical edited book. The strength is that the authors are permitted more freedom and, therefore, can be more creative than they would be in the more restrictive format of the peer-reviewed journal. The weakness of such books is that they do not always read as an integrated document. As a result, there are some useful and fascinating chapters in the book, although it would be hard to imagine a person reading the book from cover to cover.

The book is divided into eleven chapters. The first chapter, written by the editor, introduces the theme and explains the logic of how the rest of the book is structured. What is noteworthy about this introductory chapter is that it is more interesting than most introductory chapters in edited books. I would say that the author makes the topic more interesting to most readers, since some tourism history and analysis is also included in this first chapter. This introductory chapter encourages readers to read the rest of the book, rather than just offer a dry introduction doing little more than informing the reader of the structure of the book and wasting ink and paper.

The theme of the book is interesting, although some of the chapters deal more directly with the theme than others. If one were to ignore the theme of the book, the book would still have interesting chapters and information for many readers.

The chapters, apart from the introductory one, are structured under three different sections/parts. The first part is "Transnational Spaces: from Mountains to World's Fairs" and it deals with different histories-the history of the seaside resort, the history of nudism at Cap D'Agde, the history of alpine resorts, and the history of world's fairs. Chapter Two is a history of the modern seaside resorts and its evolution as a location for the modern tourist. It makes for interesting reading, dealing with such issues as the cultural clash that eventually led to the acceptance of the bikini as acceptable beachwear. This chapter is actually quite BOOK REVIEW 
interesting, since readers can imagine parallels in today's world with some of the cultural clashes occurring within Europe in the previous century.

Chapter Three focuses upon the evolution of nudism in France at Cap D'Agde and the ongoing issues faced by the various groups involved in this-the host population's desire for economic benefit but with concerns regarding traditional conceptualizations of decency, fragmentation between the different types of tourists (swingers and naturists), and the difficulties faced by local authorities balancing economic benefits with pressures to uphold decency laws. In effect, this is a history that deals with the common issue of economics, cultural clashes, and political responses that are common in a typical tourism development scenario but at an exaggerated level, since nudity plays a central role.

Chapter Four is an interesting exploration of alpine tourism, discussing the invention of the use of altitude as a principle to develop a tourism product and Switzerland's attainment of a privileged position in alpine tourism. Chapter Five explores the history of world's fairs in Europe between 1851 and 1937, the history of them and issues dealing with cultural interchange in the fair's setting.

The second part is "Selling the National in a Transnational Context." This second part is composed of three chapters. Chapter Six is an exploration of Budapest and its tourism promotion from 1885-1940. Chapter Seven gives a history of tourism in France and how the public and private sectors functioned to deal with international tourism and publicize the French product abroad from the early $20^{\text {th }}$ century. Chapter Eight deals with Ireland and the development of the tourism product of Ireland, highlighting where ideas for tourism development came from.

The third part is "The Politics of Transnational Tourism." This part is composed of three chapters. Chapter Nine deals with the Soviet experience of tourism. Chapter Ten is an intriguing look into tourism conferences in Hitler's Germany and the conflict between a state that wanted economic self-sufficiency and a tourism industry that valued foreign tourists. Chapter Ten is an interesting look at the effort to make Berlin's TV Tower's Information Center meet world standards in East Germany, in order to make a political statement to domestic and foreign visitors about the triumph/success of socialism in East Germany.

There is some criticism of the book that could be made. To begin with, I feel, the book would have been stronger had it had a concluding chapter that could somehow integrate together the various chapters, what had been learned about tourism and how this could be dealt with in future research. To some extent, the editor does this in the first chapter. Admittedly, it would be difficult to write a concluding chapter tying together what had been discussed in the book. However, it may have added some theory, or suggested something that would be useful in terms of understanding how tourism developed as a general process in Europe.

As must be the case, some chapters are more interesting and thought-provoking than others. For me, the first four chapters are the ones that I find most fascinating. Chapter Two stands out as an interesting background work for the discussion of the development of modern beach holiday. I would think that this would be a good article to cite for researchers because it is an interesting short article that succinctly deals with how modern sun, sand, and sea tourism developed. It would also be good background for undergraduate and postgraduate students to look into, in order to learn more about the social, political, and economic forces playing a role in the evolution of modern mass tourism.

Chapter Three, dealing with the evolution of nudism in postwar France, is especially fascinating, since it is the exploration of politics, economics, and culture clash which could be discussed in comparison to tourism development in other places. This chapter would be especially useful for undergraduate students, since they would likely see the conflicts within a European context, because they have been repeatedly preconditioned to think that such cultural conflicts typically 
happen between Europeans/Westerners and peoples in less developed countries. In addition, students will likely read this article and have an opinion on it, since, in my experience, students find discussions of nudity and sexuality fun, this natural attraction to the topic can be used to deal with important questions of public policy, economic development, and the impact of tourism on the host society. Indeed, the "sexy" topic can make this a useful chapter for teaching, especially to undergraduates, since they are almost guaranteed to read this article if it is assigned.

The Second Part of the book (Chapters Six, Seven, and Eight) is also useful and interesting, since the chapters illustrate how state and private organizations function in order to promote tourism abroad. What is intriguing about this Second Part is the recurring theme of state involvement in promotion and internal regulation of tourism in three different places in Europe. This is something that I would like to have seen in a concluding chapter, a note of how and when the state jumps into the game of tourism development and whether this is a reaction to private sector forces or some sort of social force. However, this preference for generalizable principles over details about specific experiences may simply be my bias as a political scientist.

One chapter that stands out as being unique and interesting for Westerners is Chapter Nine, since it deals with the Soviet experience. This model of tourism development largely absent market forces is intriguing and beguiling to those of us who grew up in market-dominated economies and who deal with tourism as something that is almost entirely marketoriented. Undergraduate and postgraduate students could and should find this chapter a challenge to their preconceptions of tourism and what causes its development, since it deals with tourism development with little concern for market forces, the influence of prerevolutionary organizations on tourism development during Soviet times, and the idea that tourism is a tool in class struggle.

The language of the book is a plus, as I see it, since it is not filled with jargon or much technical language. Therefore, the book is accessible to most undergraduate students. One surprising thing is that there are only four figures in the book, three of which occur in Chapter Five. I would have expected more figures and tables in a book of this length.

In conclusion, I find this book to be a useful and interesting book for college/university students and for researchers. Due to the wide range of topics discussed, there is something for everyone. Although it may not be a "must" for many libraries, I think it would be a good book to use chapters from for teaching about the history and politics of tourism for undergraduate students and postgraduate students. It also has significant value for researchers as a reference for such issues as the history of modern sun, sand, and sea tourism, alpine tourism, and Soviet tourism. 